\title{
ABNORMALITIES IN ${ }^{15}$ EXCRETION RATES AFTER INGESTION OF TAGGED GLYCINE IN CUSHING'S SYNDROME AND FOLLOWING ACTH ADMINISTRATION ${ }^{1}$
}

\author{
By WILLIAM PARSON, K. R. CRISPELL, AND ARTHUR EBBERT, JR. \\ (From the Department of Internal Medicine, University of Virginia, Charlottesville, Va.)
}

(Submitted for publication February 23, 1952; accepted March 24, 1952)

The purpose of this paper is to report studies of excretion rates of isotopic nitrogen, $\mathrm{N}^{15}$, following the ingestion of glycine in which the isotope was chemically incorporated. The studies were carried out on three patients with untreated Cushing's syndrome, and on two of these patients after receiving therapy in the form of X-ray to the pituitary and testosterone propionate respectively. The control studies on healthy volunteers and studies on two of these volunteers after receiving ACTH on three occasions are also reported.

\section{MATERIALS AND METHODS}

All subjects were maintained on a constant diet containing approximately $1 \mathrm{gm}$. of protein per kilogram of body weight. The nitrogen balance was estimated by analysis of an aliquot of a 24 hour urine specimen by the macro Kjeldahl technique (1). An analysis of an aliquot of the diet was made at least once for each study. The stool nitrogen was assumed to be $1.3 \mathrm{gm}$. daily (2). Breakfast contained, in addition to dietary glycine, a measured amount of glycine which varied from 40 to $120 \mathrm{mg}$./ $\mathrm{Kg}$. of body weight in different experiments. On the test day, instead of an addition of the ordinary glycine, the subject received an equivalent amount of additional glycine in which isotopic nitrogen, $\mathrm{N}^{15}$, had been chemically incorporated. The amount of $\mathrm{N}^{15}$ ingested varied from 1 to $3 \mathrm{mg}$. $/ \mathrm{Kg}$. of body weight. Urine collections were made every six hours for the first 48 hours, every 12 hours for the next 48 hours, and a final 24 hour collection was made on the fifth day.

An aliquot of each urine specimen was prepared for the mass spectrometer by the method of Sprinson and Rittenberg (3), utilizing the macro Kjeldahl technique with mercuric sulfate as a catalyst, digestion being carried out for 12 hours. The ammonia was distilled into hydrochloric acid, the nitrogen being liberated from the ammonium chloride with sodium hypobromite in an appropriate vacuum system.

The $\mathrm{N}^{15} / \mathrm{N}^{14}$ ratio was then determined by means of the mass spectrometer of the Nier type with a single slit beam with an accuracy of $\pm .002 \%$ atom excess.

\footnotetext{
1 We wish to thank Miss Sarah Brent and Miss Sara Crumley of the Dietary Department, University of Virginia Hospital, for their helpful assistance.
}

The rate of excretion of ingested $\mathrm{N}^{15}$ was determined in the following subjects:

1. Eight studies on seven healthy volunteers-K. C., A. W., A. E., A. W., R. H., J. M., ( $\left.\sigma^{\prime}\right)$; S. B. ( $($ ).

2. Four studies on two female patients (M. C. and D. M.) with Cushing's syndrome in nitrogen equilibrium.

3. One female patient (E. D.) with Cushing's syndrome in slightly negative nitrogen balance.

4. Patient M. C. with Cushing's syndrome in positive nitrogen balance while receiving $25 \mathrm{mg}$. of testosterone propionate daily after pretreatment with testosterone propionate $25 \mathrm{mg}$. daily for five days.

5. Patient E. D. with Cushing's syndrome in slightly positive nitrogen balance five months after having received X-ray therapy to pituitary.

6. Three studies on two healthy volunteers while receiving ACTH. In study No. 1 on A. W., the subject received ACTH $25 \mathrm{mg}$. every six hours for six doses beginning at the time the $\mathrm{N}^{15}$ was administered. In study No. 2 on A. W., the subject received two 25 mg. injections of ACTH every four hours before the $\mathrm{N}^{15}$ was given, and $25 \mathrm{mg}$. every four hours for six doses after the $\mathrm{N}^{15}$ was given. ACTH induced negative nitrogen balance each time. Subject A. E. received four 25 $\mathrm{mg}$. injections of ACTH every four hours before the $\mathrm{N}^{15}$ was given and $25 \mathrm{mg}$. every four hours for four doses after the $\mathrm{N}^{15}$ was given; nitrogen balance was maintained throughout.

\section{RESULTS}

It should be noted that healthy subjects, known to be in nitrogen equilibrium on a diet containing approximately $1 \mathrm{gm}$. protein per kilogram of body weight, excreted the ingested $\mathrm{N}^{15}$ at a remarkably similar rate (Figure 1, Tables I and II). This excretion of $25.9 \%$ (S.D. \pm 1.6 ) in 24 hours compares favorably with the rate of $30 \%$ reported by Sprinson and Rittenberg (4). Our studies corroborated Rittenberg's observation that the $\mathrm{N}^{15}$ was mainly in the urea fraction. It is of interest that the excretion rates were apparently uninfluenced by the range of tagged glycine ingested from $40 \mathrm{mg} . / \mathrm{Kg}$. to $120 \mathrm{mg} . / \mathrm{Kg}$. in our hands and $10 \mathrm{mg} . / \mathrm{Kg}$. by Sprinson and Rittenberg (4). This constancy of $\mathrm{N}^{15}$ excretion on a "normal" 


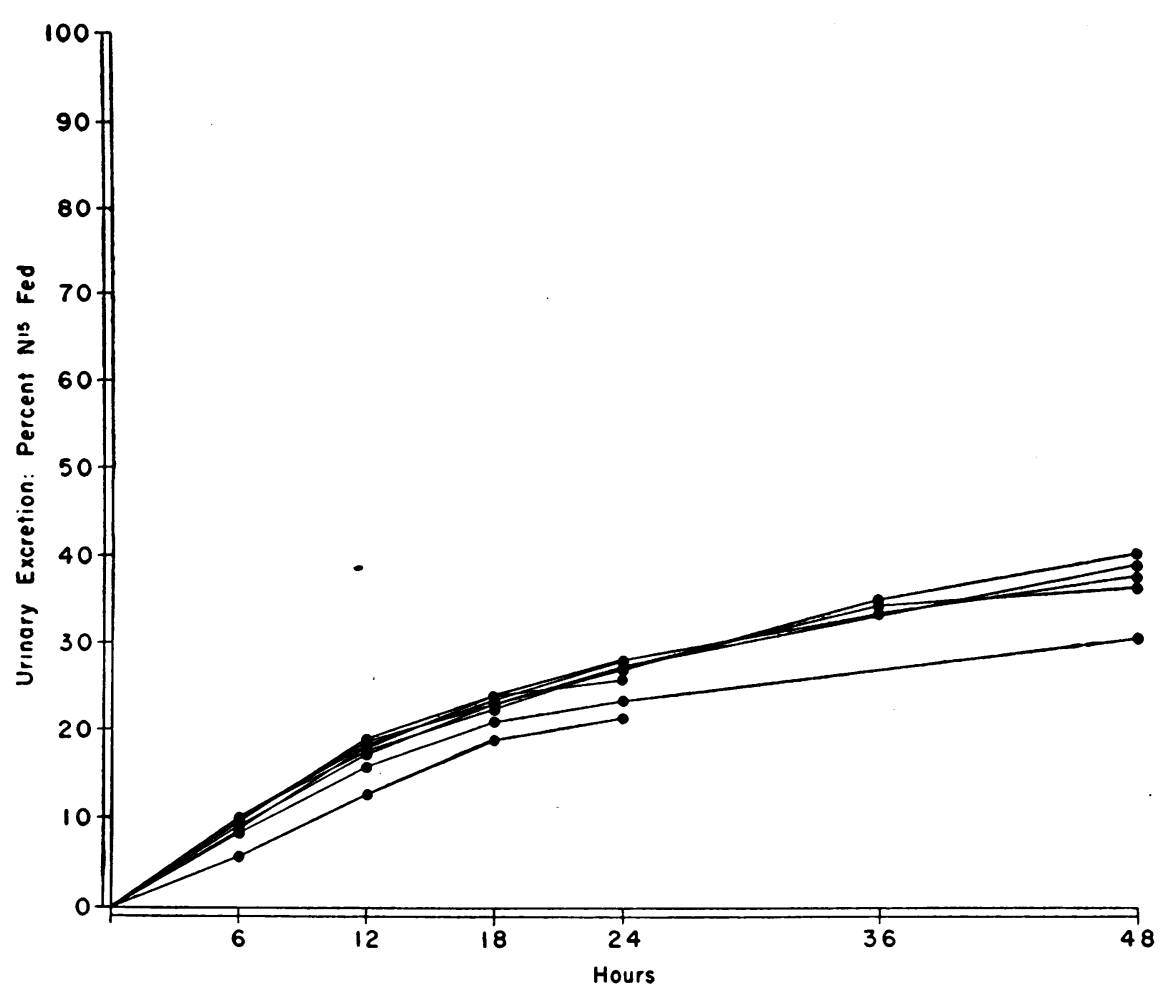

Fig. 1. Accumulative $N^{15}$ Excretion Plotted as Percentage of $N^{15}$ Ingested in Healthy Subjects in Nitrogen Equilibrium on a Standard Diet

TABLE I

\begin{tabular}{|c|c|c|c|c|c|c|c|c|c|c|c|}
\hline \multirow{3}{*}{ Subject } & \multirow{3}{*}{$\begin{array}{c}\text { Wt. range } \\
\left(K_{g .}\right)\end{array}$} & \multicolumn{10}{|c|}{ Daily nitrogen balance } \\
\hline & & \multicolumn{5}{|c|}{ Days before tag } & \multicolumn{5}{|c|}{ Days after tag } \\
\hline & & 5 & 4 & 3 & 2 & 1 & 1 & 2 & 3 & 4 & 5 \\
\hline $\begin{array}{l}\text { Normals } \\
\text { A. W. } 1 \\
\text { A. W. } 2 \\
\text { R. H. } 1 \\
\text { K. C. } \\
\text { S. B. } \\
\text { A. E. } \\
\text { J. M. } \\
\text { A. W. }\end{array}$ & $\begin{array}{l}95.4-97.7 \\
91.8-93.6 \\
73.6-74.2 \\
77.8-78.3 \\
51.4-52.2 \\
76.6-77.8 \\
80.0-80.1 \\
82.0-82.5\end{array}$ & $\begin{array}{r}-1.2 \\
-0.2 \\
0.0 \\
+0.3 \\
-0.8 \\
-3.8 \\
-1.0\end{array}$ & $\begin{array}{r}-1.4 \\
-0.1 \\
+1.0 \\
-1.1 \\
-1.2 \\
+0.9 \\
-3.3 \\
0.0\end{array}$ & $\begin{array}{l}-0.2 \\
-0.2 \\
+0.9 \\
+0.8 \\
-0.6 \\
-0.5 \\
-2.1 \\
-1.1\end{array}$ & $\begin{array}{l}-0.3 \\
-0.1 \\
-0.4 \\
+0.7 \\
-0.8 \\
-0.1 \\
-1.2 \\
+0.7\end{array}$ & $\begin{array}{l}-1.0 \\
-0.1 \\
-1.4 \\
+0.9 \\
-1.2 \\
+0.6 \\
-0.3 \\
-0.2\end{array}$ & $\begin{array}{l}-0.2 \\
-0.1 \\
+0.7 \\
+0.6 \\
-0.4 \\
+0.6 \\
-0.6 \\
-0.6\end{array}$ & $\begin{array}{l}+0.2 \\
-0.7 \\
-1.4 \\
-0.9 \\
-0.7 \\
-0.2 \\
-0.3 \\
-0.4\end{array}$ & $\begin{array}{l}+0.4 \\
-0.5 \\
+0.6 \\
-0.3 \\
+0.3 \\
+0.4 \\
-0.2\end{array}$ & $\begin{array}{l}+0.7 \\
-0.4 \\
\overline{-0.9} \\
\overline{+0.1} \\
+2.0\end{array}$ & $\begin{array}{l}\frac{-1.1}{-0.4} \\
\frac{-1.2}{\overline{-}} \\
+1.6\end{array}$ \\
\hline $\begin{array}{l}\text { Cushing's syndrome } \\
\text { M. C. } 1 \\
\text { M. C. } 2 \\
\text { M. C. } 3 \\
\text { M. C. } 4^{*} \\
\text { E. D. } 1 \\
\text { E. D. } 2 \dagger \\
\text { D. M. }\end{array}$ & $\begin{array}{l}62.8-63.6 \\
63.5-63.8 \\
61.3-61.6 \\
63.4-65.0 \\
73.3-73.9 \\
72.4-73.9 \\
66.7-67.5\end{array}$ & $\begin{array}{r}-\overline{-0.1} \\
0.0 \\
+2.0 \\
-1.7 \\
+2.3 \\
+0.9\end{array}$ & $\begin{array}{l}+0.5 \\
-0.2 \\
+0.2 \\
+2.3 \\
-1.9 \\
+1.4 \\
+1.2\end{array}$ & $\begin{array}{l}-0.1 \\
-0.4 \\
-0.4 \\
+2.6 \\
-1.5 \\
+2.6 \\
-0.3\end{array}$ & $\begin{array}{l}-0.4 \\
-0.4 \\
-0.5 \\
+2.6 \\
-2.2 \\
+2.3 \\
-1.2\end{array}$ & $\begin{array}{r}+1.4 \\
-0.3 \\
-0.4 \\
+3.7 \\
-1.4 \\
+1.6 \\
+0.1\end{array}$ & $\begin{array}{r}+0.1 \\
-0.5 \\
-0.5 \\
+3.0 \\
-2.3 \\
+0.6 \\
+0.6\end{array}$ & $\begin{array}{l}+0.4 \\
-0.7 \\
-0.4 \\
+3.2 \\
-1.4 \\
+1.6 \\
+1.8\end{array}$ & $\begin{array}{r}+0.3 \\
+0.6 \\
0.0 \\
+2.6 \\
-1.4 \\
+1.8 \\
+0.7\end{array}$ & $\begin{array}{l}+0.3 \\
+0.2 \\
-0.2 \\
+2.5 \\
-2.4 \\
+0.9 \\
-0.8\end{array}$ & $\begin{array}{r}+0.6 \\
-0.7 \\
+3.1 \\
-0.3 \\
+1.9 \\
+1.2\end{array}$ \\
\hline $\begin{array}{l}\text { Normals plus ACTH } \\
\text { A. W. } 1 \\
\text { A. W. } 2 \\
\text { A. E. }\end{array}$ & $\begin{array}{l}91.1-93.0 \\
89.9-91.2 \\
76.5-78.6\end{array}$ & $\begin{array}{l}+1.3 \\
+2.0\end{array}$ & $\begin{array}{l}+2.2 \\
+0.7 \\
+0.3\end{array}$ & $\begin{array}{l}+1.1 \\
+1.3 \\
-1.9\end{array}$ & $\begin{array}{l}+1.1 \\
+3.5 \\
+0.5\end{array}$ & $\begin{array}{l}+0.6 \\
-1.0 \\
-1.7\end{array}$ & $\begin{array}{l}-1.9 \\
-6.4 \\
+0.4\end{array}$ & $\begin{array}{l}-4.4 \\
-3.4 \\
+0.8\end{array}$ & $\begin{array}{l}-1.3 \\
-2.3 \\
+1.0\end{array}$ & $\begin{array}{l}-2.7 \\
-3.7 \\
+0.1\end{array}$ & $\overline{-1.6}$ \\
\hline
\end{tabular}

* Patient received testosterone propionate $25 \mathrm{mg}$. daily for five days previous to and during study.

$\dagger$ Five months after X-ray therapy to pituitary. 
protein intake in healthy subjects is most impressive.

In four studies on two patients with Cushing's syndrome on diets similar to the control subjects, it was established that the patients were in nitrogen equilibrium (Table I). One additional patient was found to be in negative nitrogen balance of circa $2.0 \mathrm{gm}$. in 24 hours. All of these patients showed a striking abnormality in the excretion rates of the $\mathrm{N}^{15}$ (Figures 2 and 3, Tables I and II). The rates were $48 \%, 52 \%, 47 \%$, and $42 \%$ in 24 hours in the subjects in nitrogen equilibrium. In the patient in negative nitrogen balance the excretion rate was $50 \%$ in 24 hours. It is worthy of note that approximately $90 \%$ of the $\mathrm{N}^{15}$ was in the urea fraction of the urine in the subjects in Cushing's syndrome as in the controls.

When testosterone propionate was administered to the patient with Cushing's syndrome who was in nitrogen equilibrium she went into positive ni- trogen balance and her $\mathrm{N}^{15}$ excretion fell from the high abnormal levels ( $48 \%$ and $51 \%$ ) toward the normal (32\%) (Figure 2, Tables I and II). When $\mathrm{X}$-ray therapy was administered to a patient with Cushing's syndrome resulting in a partial clinical remission, the negative nitrogen balance became slightly positive and the high abnormal $\mathrm{N}^{15}$ excretion rate (50\%) fell toward normal (38\%) (Figure 3, Tables I and II).

On two occasions ACTH administration resulted in negative nitrogen balance in a healthy subject and the $\mathrm{N}^{15}$ excretions were abnormally high, $36 \%$ and $45 \%$, compared with his baseline of $27 \%$ (Figure 4, Tables I and II). ACTH did not disturb the nitrogen balance in another healthy subject but despite this, the $\mathrm{N}^{15}$ excretion rose from $27 \%$ to $39 \%$ (Figure 4 , Tables I and II).

This striking alteration in the handling of ingested glycine despite the maintenance of nitrogen

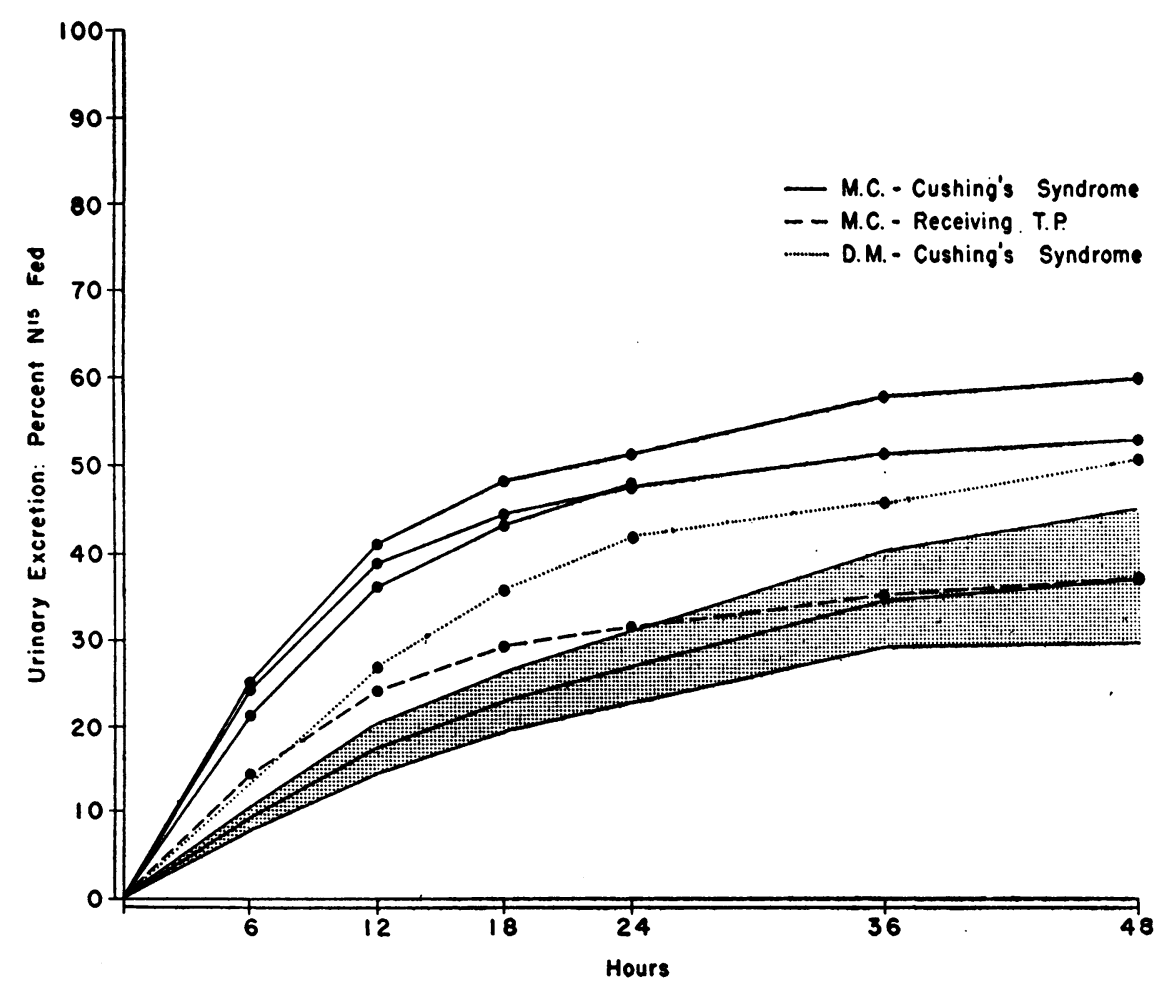

Fig. 2. Accumulative $N^{15}$ Excretion of Four Experiments on Two Patients with Cushing's Syndrome (M. C., D. M.) in Nitrogen Equilibrium on a Standard Diet. Additional Curve on Patient (M. C.) Receiving Testosterone Propionate in PosiTIVE Nitrogen BaLANCE

The hatched area portrays the mean excretion rate plus or minus two standard deviations in seven healthy subjects in nitrogen equilibrium on a standard diet. 
TABLE II

\begin{tabular}{|c|c|c|c|c|c|c|c|c|c|c|}
\hline \multirow{3}{*}{ Subject } & \multirow{3}{*}{ Weight } & \multicolumn{2}{|c|}{ Nitrogen intake } & \multicolumn{7}{|c|}{ Urinary nitrogen } \\
\hline & & N14 & N16 & $\mathbf{N}^{14}$ & \multicolumn{6}{|c|}{$\mathrm{N}^{16}$ accumulated excretion } \\
\hline & & $24 \mathrm{hrs}$. & $\begin{array}{c}\text { Single } \\
\text { dose }\end{array}$ & $24 \mathrm{hrs}$. & $6 \mathrm{hrs}$. & $12 \mathrm{hrs}$. & $18 \mathrm{hrs}$. & 24 hrs. & $48 \mathrm{hrs}$. & 24 hrs. \\
\hline $\begin{array}{l}\text { Normals } \\
\text { A. W. } 1 \\
\text { A. W. } 2 \\
\text { R. H. } \\
\text { K. C. } \\
\text { J. M. } \\
\text { A. E. } \\
\text { A. W. } \\
\text { S. B. } \\
\quad \text { Mean }\end{array}$ & $\begin{array}{l}(K \boldsymbol{g} .) \\
\\
97.0 \\
93.5 \\
74.1 \\
77.9 \\
80.0 \\
77.3 \\
82.3 \\
51.6\end{array}$ & $\begin{array}{l}(\mathrm{gm} .) \\
16.1 \\
16.1 \\
12.9 \\
14.9 \\
12.1 \\
14.3 \\
16.8 \\
8.5\end{array}$ & $\begin{array}{r}\text { (mg.) } \\
104 \\
104 \\
82 \\
33 \\
33 \\
180 \\
90 \\
150\end{array}$ & $\begin{array}{l}(\mathrm{gm.}) \\
14.8 \\
13.2 \\
10.9 \\
13.0 \\
11.4 \\
12.5 \\
16.1 \\
7.6\end{array}$ & $\begin{array}{r}(m g .) \\
10.3 \\
10.5 \\
7.4 \\
3.3 \\
2.7 \\
16.2 \\
5.7 \\
14.6\end{array}$ & \begin{tabular}{r|} 
(mg.) \\
\\
18.1 \\
18.9 \\
14.1 \\
6.1 \\
5.2 \\
32.9 \\
11.8 \\
28.2
\end{tabular} & $\begin{array}{r}\text { (mg.) } \\
\\
23.2 \\
24.3 \\
18.9 \\
\\
6.9 \\
43.3 \\
16.9 \\
35.7\end{array}$ & $\begin{array}{r}\text { (mg.) } \\
\\
28.0 \\
29.3 \\
22.2 \\
8.9 \\
7.6 \\
49.9 \\
19.7 \\
38.6\end{array}$ & $\begin{array}{l}\text { (mg.) } \\
39.8 \\
39.4 \\
33.3 \\
12.8 \\
10.2\end{array}$ & $\begin{array}{l}\quad(\%) \\
27.0 \\
28.1 \\
27.0 \\
27.0 \\
23.0 \\
27.5 \\
21.7 \\
26.0 \\
25.9 \text { S.D. } \pm 1.6\end{array}$ \\
\hline $\begin{array}{l}\text { Cushing's syndrome } \\
\text { M. C. } 1 \\
\text { M. C. } 2 \\
\text { M. C. } 3 \\
\text { M. C. } 4^{*} \\
\text { E. D. } 1 \\
\text { E. D. } 2 \dagger \\
\text { D. M. } 1 \\
\text { Mean }\end{array}$ & $\begin{array}{l}62.9 \\
63.7 \\
61.5 \\
64.7 \\
73.7 \\
73.8 \\
67.0\end{array}$ & $\begin{array}{l}10.9 \\
10.9 \\
10.9 \\
10.9 \\
14.0 \\
14.0 \\
11.8\end{array}$ & $\begin{array}{r}78 \\
39 \\
22 \\
52 \\
120 \\
180 \\
120\end{array}$ & $\begin{array}{r}9.5 \\
10.1 \\
10.1 \\
6.6 \\
15.0 \\
12.1 \\
11.1\end{array}$ & $\begin{array}{r}19.3 \\
9.9 \\
4.6 \\
7.5 \\
26.3 \\
30.3\end{array}$ & $\begin{array}{r}30.7 \\
16.2 \\
7.8 \\
12.6 \\
45.0 \\
51.9 \\
32.0\end{array}$ & $\begin{array}{r}35.3 \\
18.9 \\
9.5 \\
15.3 \\
54.7 \\
63.8 \\
43.5\end{array}$ & $\begin{array}{l}37.6 \\
20.2 \\
10.4 \\
16.6 \\
60 \\
69.2 \\
50.7\end{array}$ & $\begin{array}{l}42.1 \\
23.5 \\
19.4 \\
71.4 \\
60.4\end{array}$ & $\begin{array}{l}48.2 \\
51.7 \\
47.3 \\
31.9 \\
50.0 \\
38.3 \\
42.2 \\
47.9 \text { S.D. } \pm 3.5\end{array}$ \\
\hline $\begin{array}{l}\text { Normals plus ACTH } \\
\text { A. W. } 1 \\
\text { A. W. } 2 \\
\text { A. E. }\end{array}$ & $\begin{array}{l}91.3 \\
90.0 \\
77.6\end{array}$ & $\begin{array}{l}16.1 \\
16.0 \\
14.3\end{array}$ & $\begin{array}{r}104 \\
104 \\
33\end{array}$ & $\begin{array}{l}16.4 \\
20.9 \\
12.6\end{array}$ & $\begin{array}{r}13.8 \\
17.2 \\
5.2\end{array}$ & $\begin{array}{r}25.1 \\
31.9 \\
8.8\end{array}$ & $\begin{array}{l}31.8 \\
40.1 \\
11.2\end{array}$ & $\begin{array}{l}37.3 \\
47.0 \\
13.0\end{array}$ & $\begin{array}{l}50.0 \\
60.2 \\
16.5\end{array}$ & $\begin{array}{l}36.0 \\
45.3 \\
39.4\end{array}$ \\
\hline
\end{tabular}

* Patient received testosterone propionate, $25 \mathrm{mg}$. daily for five days previous to and during the study.

$\uparrow$ Five months after X-ray therapy to pituitary.

equilibrium parallels the observations noted above in Cushing's syndrome.

\section{DISCUSSION}

The classical nitrogen balance study offers little insight concerning alterations in intermediary metabolism of amino acids and protein. Albright (5) has called attention to the common finding of "nitrogen balance" in Cushing's syndrome despite the clinical evidence of a profound disturbance in protein metabolism. A combination of nitrogen balance studies with the ingestion of glycine tagged with $\mathrm{N}^{15}$ offers new information in the study of this problem and other problems concerned with disturbances in protein metabolism.

Sprinson and Rittenberg $(4,6)$ offered a mathematical analysis of the excretion rates of $\mathrm{N}^{15}$ in healthy subjects following the ingestion of tagged glycine. With full realization of the assumptions involved, they postulated homogeneity of the "metabolic pool" and calculated its size and also the rate of tissue synthesis. We presented a preliminary report of our data (7) using this type of analysis. In the above analyses the rate of urea excretion was not considered to be a significant factor. Tarver (8) has criticized these assumptions and has pointed out that the size of the metabolic pool appeared to be too large. Rittenberg and San Pietro (9) have reappraised the problem and recalculated the size of the metabolic pool after first determining the size of the urea space. This newly derived pool size is considerably smaller and more probable than the original figures. Unfortunately the data presented here will not permit analysis by this revised technique.

However, even without mathematical treatment of the data we feel that it is of interest to report the striking alterations in the handling of the ingested $\mathrm{N}^{15}$ in Cushing's syndrome before and after therapy and in healthy subjects following the administration of ACTH. It seems reasonable to conclude from the data presented that when ni- 
trogen equilibrium exists in Cushing's syndrome, and following ACTH administration, the observed alteration from normal in $\mathrm{N}^{15}$ excretion indicates that a larger fraction than normal of ingested glycine nitrogen is converted to urea and excreted in 24 hours, and conversely, a smaller fraction is utilized for synthetic or anabolic processes. Inasmuch as the subject is in nitrogen equilibrium, it may be assumed that the rate of tissue breakdown equals the rate of tissue synthesis. When nitrogen balance is altered, as following testosterone propionate, X-ray therapy, and ACTH therapy, speculation may be unwarranted.

If one may generalize from the alteration in the handling of the tagged glycine nitrogen, these studies appear to suggest both decreased protein synthesis and increased degradation of ingested amino acids in hyperadrenocorticism, and offer partial support to Albright's concept of the role of antianabolism in this disorder. On the other hand, Kinsell and associates (10) found no de- pression of the rate of incorporation of $S^{35}$ into plasma protein following the administration of methionine tagged with $\mathrm{S}^{35}$ in Cushing's syndrome.

It is recognized that an alternative interpretation would fit the observations reported here; namely, that hyperadrenocorticism is associated with an increased turnover rate of protein in general; that is, increased synthesis and increased degradation.

However, our interpretation of the data seems more reasonable and is in general accord with isotope studies of protein metabolism and adrenal function in animals.

Friedberg (11) observed that the administration of dehydrocorticosterone to adrenalectomized animals depressed the rate of incorporation of methionine sulfur $\left(\mathrm{S}^{35}\right)$ into tissue protein.

White, Hoberman, and Szego (12) injected glycine tagged with $\mathrm{N}^{15}$ and reported a higher $\mathrm{N}^{15}$ content in the tissues of adrenalectomized fasted mice than in the normal fasted animals.

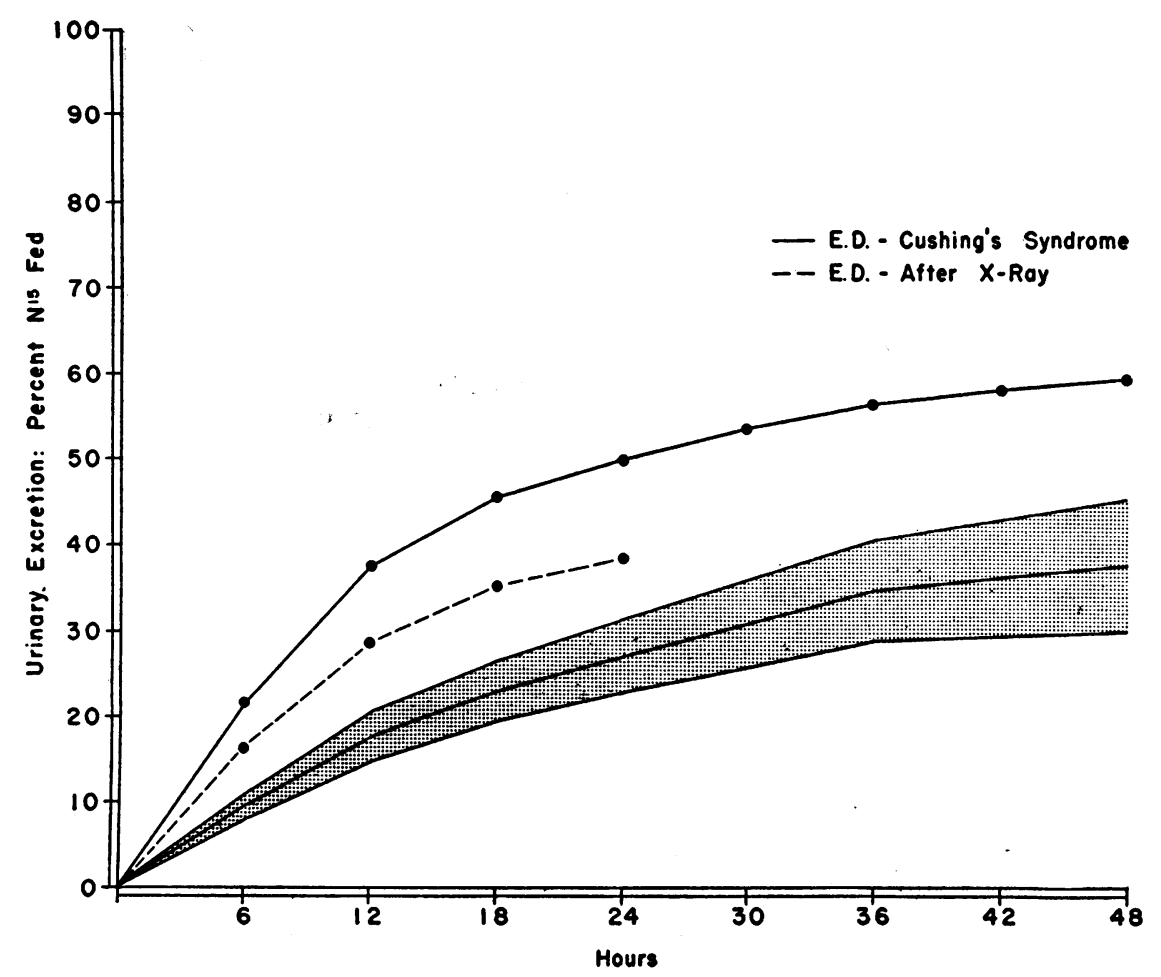

Fig. 3. Accumulative N ${ }^{15}$ Excretion in Patient (E. D.) with Cushing's Syndrome IN Two Experiments

Untreated, the patient was in mild negative nitrogen balance; five months after X-ray treatment, was in mild positive nitrogen balance.

The hatched area is as described in Figure 2. 


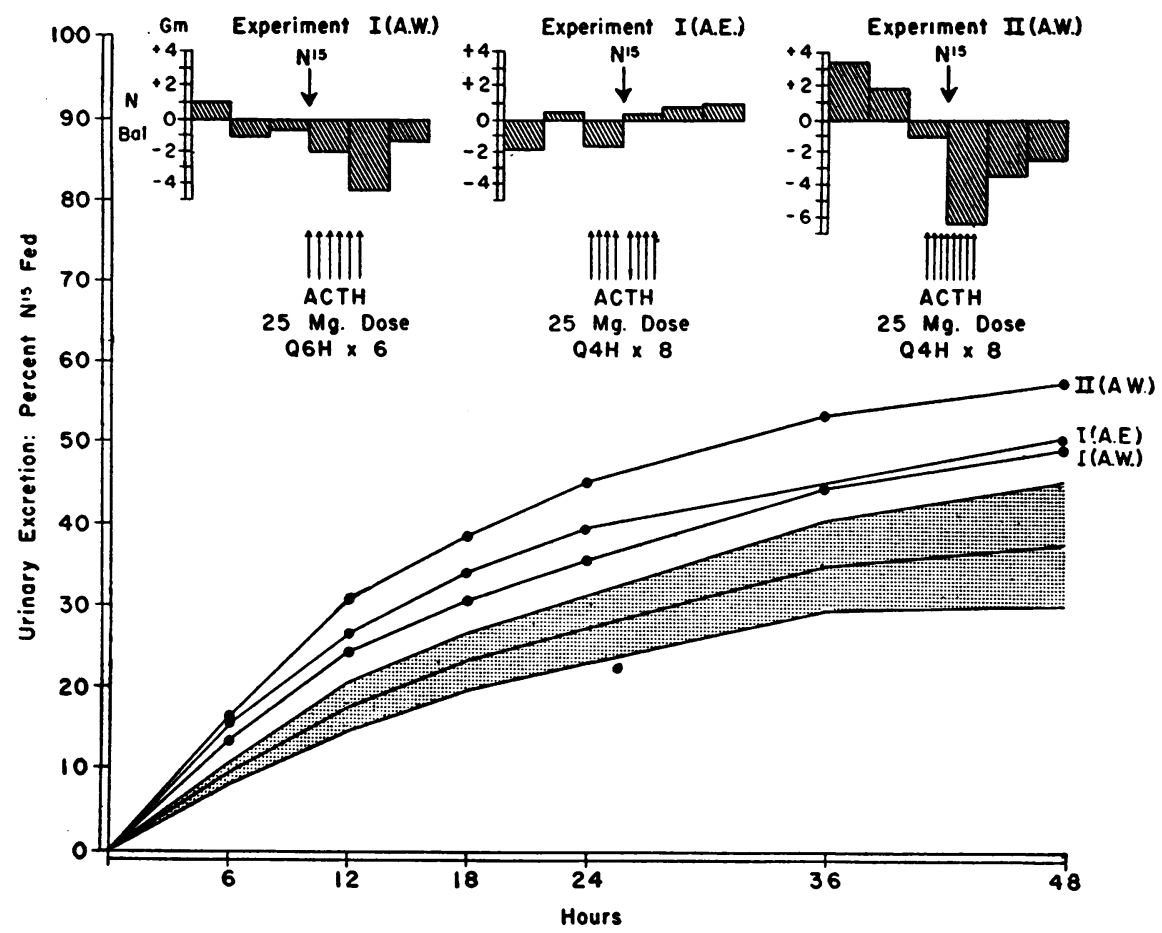

Fig. 4. Accumulative $\mathrm{N}^{15}$ Excretion Rates in Three Experiments on Two Healthy Subjects (A. W., A. E.) on a Standard Diet While Receiving ACTH

The mode of administration of ACTH and the alterations in nitrogen balance in each experiment are portrayed.

The hatched area is as described in Figure 2.

Clark (13) fed glycine tagged with $\mathrm{N}^{15}$ to normal and adrenalectomized rats. He injected cortisone and studied urinary excretion rates. Without publication of the data, he reported, "In the animals receiving cortisone there was a decrease in protein synthesis as compared to the control animals."

Hoberman (14) injected fasted rats with glycine tagged with $\mathrm{N}^{15}$ and studied urinary excretion rates after hormonal manipulation of various sorts. It is germane to this paper that among his conclusions he states, "the biochemical reactions leading to the formation of protein are accelerated in adrenalectomized and hypophysectomized rats" and finally, "the synthesis of body proteins is diminished in those animals in which the adrenal cortex is hyperactive." He subjected his data to mathematical treatment somewhat similar to Sprinson and Rittenberg (4), and hence it is open to the same criticism.

Marshall and Friedberg (15) reported that ACTH administration to hypophysectomized rats decreased the uptake of the $\mathrm{C}^{14}$ label of carboxyl marked glycine in muscle and kidney protein.

Barton (16) has injected glycine-2-C ${ }^{14}$ into normal and adrenalectomized mice. He has found in either case that prior injection of a small dose of adrenal cortical extract will inhibit the abrupt rise in the specific activity of the uncombined glycine in the liver, and the catabolism of the glycine is increased.

\section{SUMMARY AND CONCLUSIONS}

1. The rate of $\mathrm{N}^{15}$ excretion in the urine following ingestion of tagged glycine has been determined on healthy subjects in nitrogen equilibrium on a standard diet.

2. In four studies on patients with Cushing's syndrome an increased rate of excretion of $\mathrm{N}^{15}$ was noted while the subject was in nitrogen equilibrium. In one patient in negative nitrogen balance, there was a similar degree of alteration in $\mathrm{N}^{15}$ excretion.

3. An X-ray induced partial remission in one 
case of Cushing's syndrome and testosterone propionate administration in another resulted in positive nitrogen balance and a fall in the $\mathrm{N}^{15}$ excretion rate toward normal.

4. Administration of ACTH on three occasions to two healthy subjects resulted in negative nitrogen balance on two occasions only. In all these studies the $\mathrm{N}^{15}$ excretion rate was similarly increased.

5. It is suggested that these data support the concept that hyperadrenocorticism may be characterized by an increased rate of degradation of ingested amino acid and decreased protein synthesis.

\section{ACKNOWLEDGMENTS}

We wish to express our appreciation to the group at Tulane University in collaboration with whom these studies were initiated. These men include Dr. R. T. Nieset, Department of Biophysics, Dr. A. G. C. White, Department of Biochemistry, Dr. H. Mayerson, Department of Physiology, and Dr. C. Lyons, Department of Surgery.

\section{REFERENCES}

1. Hawk, P. B., Oser, B. L., and Summerson, W. H., Practical Physiological Chemistry. The Blakiston Co., Philadelphia, Pa., 1947, 12th ed.

2. Reifenstein, E. C., Jr., Albright, F., and Wells, S. L., The accumulation, interpretation, and presentation of data pertaining to metabolic balances, notably those of calcium, phosphorus, and nitrogen. J. Clin. Endocrinol., 1945, 5, 367.

3. Sprinson, D. B., and Rittenberg, D., The rate of utilization of ammonia for protein synthesis. J. Biol. Chem., 1949, 180, 707.

4. Sprinson, D. B., and Rittenberg, D., The rate of interaction of the amino acids of the diet with the tissue proteins. J. Biol. Chem., 1949, 180, 715.

5. Albright, F., Cushing's syndrome. Its pathological physiology, its relationship to the adreno-genital syndrome, and its connection with the problem of the reaction of the body to injurious agents ("alarm reaction" of Selye). The Harvey Lectures, 19421943, 38, pp. 123-186.

6. Rittenberg, D., Dynamic aspects of the metabolism of amino acids. The Harvey Lectures, 1948-1949, 44, p. 200.

7. Parson, W., Crispell, K. R., and Ebbert, A., Jr., Amino acid metabolism in Cushing's syndrome and ACTH-induced hyperadrenocorticism using N-15 incorporated in glycine. J. Clin. Endocrinol., 1951, $12,773$.

8. Greenberg, D. M., Amino Acids and Proteins; Theory, Methods, Application. Charles C Thomas Co., Springfield, I1l., 1951, p. 828.

9. Ciba Foundation Conference on Isotopes in Biochemistry. The Blakiston Co., Philadelphia, Pa., 1951, p. 190.

10. Kinsell, L. W., Margen, S., Tarver, H., Frantz, J. McB., Flanagan, E. K., Hutchin, M. E., Michaels, G. D., and McCallie, D. P., Studies in methionine metabolism. III. The fate of intravenously administered $\mathrm{S}^{35}$-labeled-methionine in normal adult males, in patients with chronic hepatic disease, "idiopathic" hypoproteinemia and Cushing's syndrome. J. Clin. Invest., 1950, 29, 238.

11. Friedberg, F., Thesis, University of California, 1947.

12. White, A., Hoberman, H. D., and Szego, C. M., Influence of adrenalectomy and fasting on the incorporation of isotopic nitrogen into the tissues of mice. J. Biol. Chem., 1948, 174, 1049.

13. Clark, I., Effect of cortisone on protein metabolism in the rat as studied with isotopic glycine. Federation Proc., 1950, 9, 161.

14. Hoberman, H. D., Endocrine regulation of amino acid and protein metabolism during fasting. Yale $\mathrm{J}$. Biol. \& Med., 1950, 22, 341.

15. Marshall, L. M., and Friedberg, F., Effect of ACTH on the incorporation of $\mathrm{C}-14$ of glycine in tissue protein. Endocrinology, 1951, 48, 113.

16. Barton, A. D., Influence of adrenalectomy and adrenal cortical hormones in vivo on metabolism of glycine in the liver. Federation Proc., 1951, 10, 160. 